\title{
Si-Tricalcium Phosphate Cement: Preparation, Characterization and Bioactivity in SBF
}

\author{
Mariana Motisuke ${ }^{\mathrm{a}, \mathrm{b}, *}$, Raúl García Carrodeguas, Cecília Amélia de Carvalho Zavaglia ${ }^{\mathrm{b}, \mathrm{d}}$ \\ ${ }^{a}$ Instituto de Ciência e Tecnologia - ICT, Universidade Federal de São Paulo - UNIFESP, \\ CEP 12.231-280, São José dos Campos, SP, Brazil \\ ${ }^{b}$ Instituto Nacional de Ciência e Tecnologia em Biofabricação - INCT/Biofabris, \\ Universidade Estadual de Campinas - UNICAMP, Campinas, SP, Brazil \\ 'Instituto de Cerámica y Vidrio - ICV, \\ Consejo Superior de Investigaciones Científicas - CSIC, Madrid, España \\ ${ }^{d}$ Laboratório de Biomateriais e Biomecânica - LABIOME, Faculdade de Engenharia \\ Mecânica-FEM, Universidade Estadual de Campinas - UNICAMP, Campinas, SP, Brazil
}

Received: March 10, 2011; Revised: August 3, 2011

\begin{abstract}
There are evidences considering the effectiveness of $\mathrm{Si}$ on enhancing biological properties of calcium phosphates; however, there are not many works relating to the Si-alpha-TCP bone cement. The influence of silicon doping on the properties of $\alpha$-TCP cement was analyzed. Si-TCP was obtained by a solid state reaction employing $\mathrm{CaCO}_{3}, \mathrm{CaHPO}_{4}$ and $\mathrm{CaSiO}_{3}$ and powder was analyzed by XRD, FTIR, XRF and BET specific area. Cement samples were analyzed for their surface of fracture morphology, mechanical resistance and SBF bioactivity. Cement mechanical resistance was not satisfactory for biomedical application; nonetheless, sample's surface was coated by an apatite layer after immersion in SBF. Notwithstanding, to ensure that silicon is the element responsible for increasing the material's bioactivity it is necessary to evaluate the in vivo performance of the bone cement obtained in this work.
\end{abstract}

Keywords: calcium phosphate cements, tricalcium phosphate, wollastonite, silicon-doped tricalcium phosphate, biomedical application

\section{Introduction}

Ionic substitution into calcium phosphate's crystalline structure has been reported as an important path on the development of orthopedic implants and tissue engineering scaffolds once it is possible to control material's thermal stability, in vivo solubility and cell adhesion and proliferation ${ }^{1-12}$. For instance, silicon doped $\alpha$-tricalcium phosphate ( $\mathrm{Si}-\alpha-\mathrm{TCP})$ is receiving great attention due to the increased bioactivity and the lower synthesis temperature promoted by the partial substitution of silicon into the tetrahedral phosphorus sites of tricalcium phosphate $e^{4-12}$.

Usually, $\mathrm{Si}-\alpha-\mathrm{TCP}$ is synthesized either by wet precipitation from calcium nitrate and ammonium phosphate solutions in the proper ratio and in the presence of ammonia and colloidal silica or organic silicon compounds, followed by thermal decomposition of the resulting powder ${ }^{9,10}$; by high temperature solid state reaction from mixtures of $\mathrm{CaCO}_{3}, \mathrm{CaHPO}_{4}$ or $\left(\mathrm{NH}_{4}\right)_{2} \mathrm{PO}_{4}$, and $\mathrm{Ca}_{2} \mathrm{SiO}_{4}$, (or $\left.\mathrm{CaSiO}_{3}\right)^{7,13}$ or from mixtures of $\beta-\mathrm{Ca}_{3}\left(\mathrm{PO}_{4}\right)_{2}$ and $\mathrm{CaSiO}_{3}^{[14]}$

Wet precipitation method often yields to $\mathrm{Ca} /(\mathrm{Si}+\mathrm{P})$ ratio different from 1.50 unless strict control of $\mathrm{pH}$, temperature, concentration, and aging of the precipitate are maintained. On the other hand, solid state reaction method allows an accurate control of the $\mathrm{Ca} /(\mathrm{Si}+\mathrm{P})$ ratio. In spite of that, both methods possess a serious handicap; the "pure" commercial precursors commonly available (especially $\mathrm{CaCO}_{3}$ and $\mathrm{CaHPO}_{4}$ ) always contain a few tenths per cent of $\mathrm{Mg}$ which have been recognized as an effective inhibitor of $\beta \rightarrow \alpha$ transformation in TCP, and acts as a stabilizer of the low temperature phase $\beta$-TCP ${ }^{11,15,16}$.
Extra "pure" commercial reagents are very expensive and not often available.

There are many evidences considering the effectiveness of $\mathrm{Si}$-alpha-TCP and Si-HA on enhancing biological properties of these materials ${ }^{4-12}$, however, there are not many works relating to the Si-alpha-TCP bone cement which should also have enhanced biological properties. Thus, the process by which the transformation of Si-alpha-TCP into apatite occurs must be investigated. There are evidences but not too many certainties that silicon is responsible for changes on the setting reaction process and in the final properties of the bone cement ${ }^{6,7,11}$. Thus, the objective of this report is to characterize the calcium phosphate cement obtained from silicon doped tricalcium phosphate (Si-TCP).

\section{Materials and Methods}

\subsection{TCP powders synthesis and milling}

Silicon doped tricalcium phosphate, $\mathrm{Si}-\mathrm{TCP}$, was synthesized by solid state reaction of an appropriate mixture of $\mathrm{CaCO}_{3}$ (Synth, Brazil; 0.16 wt. (\%) $\mathrm{SiO}_{2} ; 0.57$ wt. (\%) $\mathrm{MgO} ; 0.17$ wt. (\%) $\mathrm{Al}_{2} \mathrm{O}_{3} ; 0.18$ wt. (\%) $\mathrm{SrO}$ ), $\mathrm{CaHPO}_{4}\left(\right.$ Synth, Brazil; 0.27 wt. (\%) Mg) and $\mathrm{CaSiO}_{3}$ (Vetec, Brazil; 0.17 wt. (\%) $\mathrm{Al}_{2} \mathrm{O}_{3}$; 0.16 wt. (\%) $\mathrm{MnO}$; 0.66 wt. (\%) $\mathrm{Fe}_{2} \mathrm{O}_{3}$ ) at $1400{ }^{\circ} \mathrm{C}$ during 6 hours. Heating rate was $10^{\circ} \mathrm{C} / \mathrm{min}$ and after the dwelling time the sample was left inside the furnace to cool down to room temperature. Afterwards, the powder was ball milled for one 
week. TCP BET specific surface area and particle size distribution were determined using Micromeritics, ASAP 2010 and Malvern Mastersizer S, respectively.

\subsection{Calcium phosphate cement}

Cement samples were prepared using an aqueous solution containing 2.5 wt. (\%) of $\mathrm{Na}_{2} \mathrm{HPO}_{4}$ and 1.5 wt. (\%) of $\mathrm{C}_{6} \mathrm{H}_{8} \mathrm{O}_{7}$ (citric acid) with a liquid-to-powder ratio equal to $0.60 \mathrm{~mL} \cdot \mathrm{g}^{-1}$. After molding in Teflon molds $(6 \times 12 \mathrm{~mm}$ and $12 \times 6 \mathrm{~mm})$ samples were left in a $100 \%$ relative moisture environment for 24 hours. Then, cement cylinders were polished, demolded and immersed in SBF for 24 and 168 hours at $37^{\circ} \mathrm{C}$. After each immersion period, samples were gently rinsed with distillated water, immersed in acetone to stop the setting reaction and dried at $100{ }^{\circ} \mathrm{C}$ for 6 hours.

To estimate $\mathrm{pH}$ evolution during cement setting reaction, Si-TCP $\mathrm{pH}$ evolution as a function of time was evaluated by preparing a Si-TCP suspension $\left(100 \mathrm{mg} \cdot \mathrm{mL}^{-1}\right)$ in a buffer solution $(\mathrm{pH}=7.4)$. The suspension was maintained at $37{ }^{\circ} \mathrm{C}$ and the $\mathrm{pH}$ was measured in different periods of times during 14 days.

Cements samples were mechanical tested (MTS, Test Star II) and the morphology of the surface of fracture was analyzed by scanning electron microscopy (JEOL-6400).

\subsection{X-ray diffraction}

Crystalline phase purity was analyzed by X-ray diffraction (Rigaku DMAX-2200, CuK $\alpha$, Ni filter, 20 a $40^{\circ}(2 \theta), 0.02^{\circ} / \mathrm{s}, 40 \mathrm{kV}$ e $40 \mathrm{~mA}$ ). JCPDS files used for phase identification were 09-0348 for $\alpha$-TCP, 09-0169 for $\beta$-TCP and 46-0905 for CDHA (calcium deficient hydroxyapatite). $\beta$-TCP mass fraction present in the cement starting material was determined using the internal pattern $\operatorname{method}^{17}$.

\subsection{Fourier transformed infrared}

TCP powder and cement were diluted in $\mathrm{KBr}$ and FTIR analysis was carried out on a Perkin Elmer 1600 FT-IR spectrometer with a scanning range from 450 to $4000 \mathrm{~cm}^{-1}$ and resolution of $2 \mathrm{~cm}^{-1}$.

\subsection{X-ray fluorescence}

$\mathrm{TCP} \mathrm{Ca} / \mathrm{P}$ ratio was determined using a MagiX Super Q Version 3.0 X-ray fluorescence spectrometer (Philips, The Netherlands) provided with Rh X-ray tube and power generator of $2.4 \mathrm{~kW} .0 .3000 \mathrm{~g}$ of each mixture were weighed, mixed with $5.5 \mathrm{~g}$ of spectral grade $\mathrm{Li}_{2} \mathrm{~B}_{4} \mathrm{O}_{7}$ and melted in a $\mathrm{Pt} / \mathrm{Au}$ crucible and formed into disks in a special controlled furnace Perl'X3 (Philips, The Netherlands). Calibration curves were prepared using certified composition standards of natural and synthetic calcium phosphates and calcium silicates.

\subsection{Bioactivity in $S B F$}

After setting for 168 hours cements samples $(12 \times 6 \mathrm{~mm}$ discs $)$ were immersed once again in SBF at $37{ }^{\circ} \mathrm{C}$ for analyzing the occurrence of apatite precipitation on the sample' surface after one week. After the immersion time, samples were gently rinsed with distillated water and dried overnight. To verify the presence of apatite precipitation the sample surface was gold coated and was analyzed by scanning electron microscopy (JEOL -6400).

\section{Results and Discussions}

Si-TCP was obtained from the solid state reaction employed; however, due to high magnesium levels of the precursors, Si-TCP was obtained with 19 wt. (\%) of $\beta$-TCP. This element is a well established stabilizer of the $\beta$-TCP phase since it raises $\beta$-TCP thermal stability to almost $1400{ }^{\circ} \mathrm{C}$ depending on $\mathrm{Mg}$ content ${ }^{15,16}$. As it is observed on the XRD pattern of Figure 1 there is a $\beta$-TCP characteristic XRD line at approximately $28^{\circ} 2$-theta.

Indeed, the formation of tricalcium phosphate was also verified on FTIR analysis since the absorption bands present on sample's spectrum (Figure 2) are characteristic of $\alpha$-TCP as displayed on Table $1^{18,19}$.

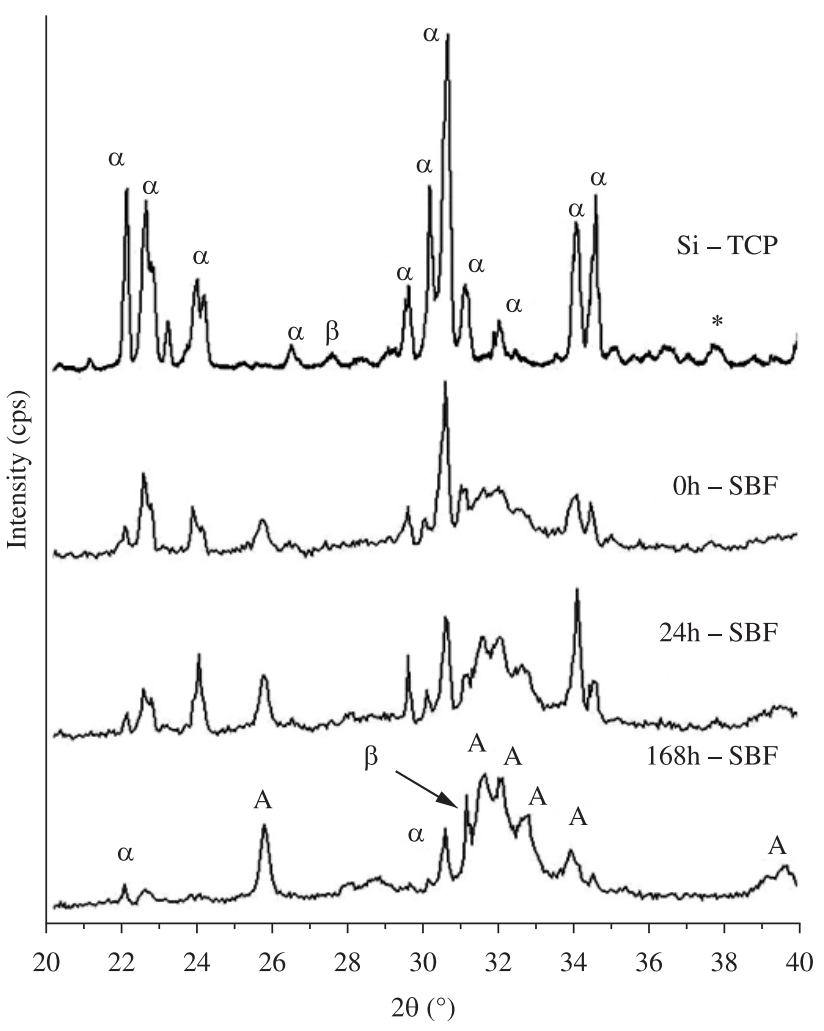

Figure 1. XRD patterns from $\mathrm{Si}-\mathrm{TCP}$ and cement samples after 0,24 and 168 hours of SBF immersion. Legend $=\alpha: \alpha$-TCP, $\beta$ : $\beta$-TCP, A: apatite, *: $\mathrm{CaO}$.

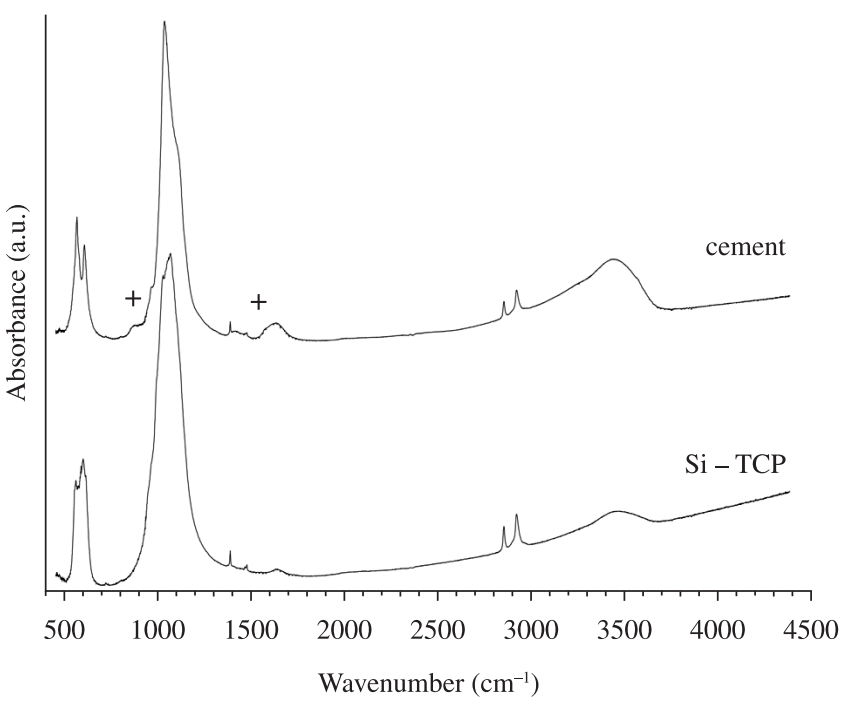

Figure 2. FTIR spectrum of $\alpha$-TCP powders and cement sample after 168 hours of setting. "+" represents $\mathrm{CO}_{3}^{2-}$ absorbance bands. 
Table 1. FTIR absorption bands of $\alpha-\mathrm{TCP}^{18}$.

\begin{tabular}{ccc}
\hline Absorption & Bond & Wavenumber $\left(\mathrm{cm}^{-1}\right)$ \\
\hline$v_{1}$ & P-O & 963 \\
\hline$v_{2}$ & OPO & 462 \\
\hline & & 1120 \\
$v_{3}$ & & 1100 \\
& P-O & 1084 \\
& & 1025 \\
& & 990 \\
\hline & & 597 \\
$v_{4}$ & OPO & 583 \\
& & 572 \\
\hline
\end{tabular}

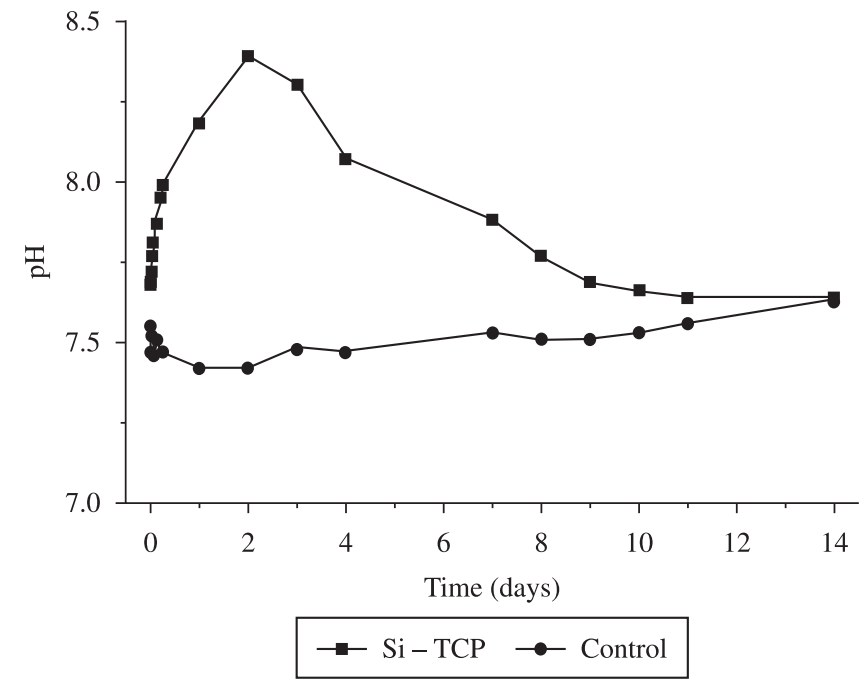

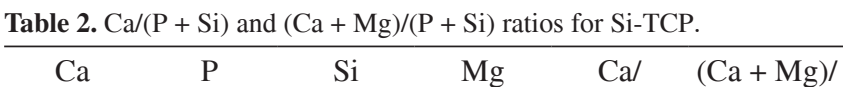

\begin{tabular}{cccccc} 
(wt. $(\%))$ & $($ wt. $(\%))$ & $($ wt. $(\%))$ & $($ wt. $(\%))$ & $(\mathrm{P}+\mathrm{Si})$ & $(\mathrm{P}+\mathrm{Si})$ \\
\hline 38.70 & 18.68 & 1.27 & 0.18 & 1.49 & 1.50 \\
\hline
\end{tabular}

Figure 3. $\mathrm{Si}-\mathrm{TCP} \mathrm{pH}$ evolution in a buffer solution $(\mathrm{pH}=7.4) . \mathrm{CaO}$ in aqueous solutions forms $\mathrm{Ca}(\mathrm{OH})_{2}$ leading to an $\mathrm{pH}$ increase which could be responsible for $\mathrm{Si}$-TCP lower reactivity during cement setting reaction.
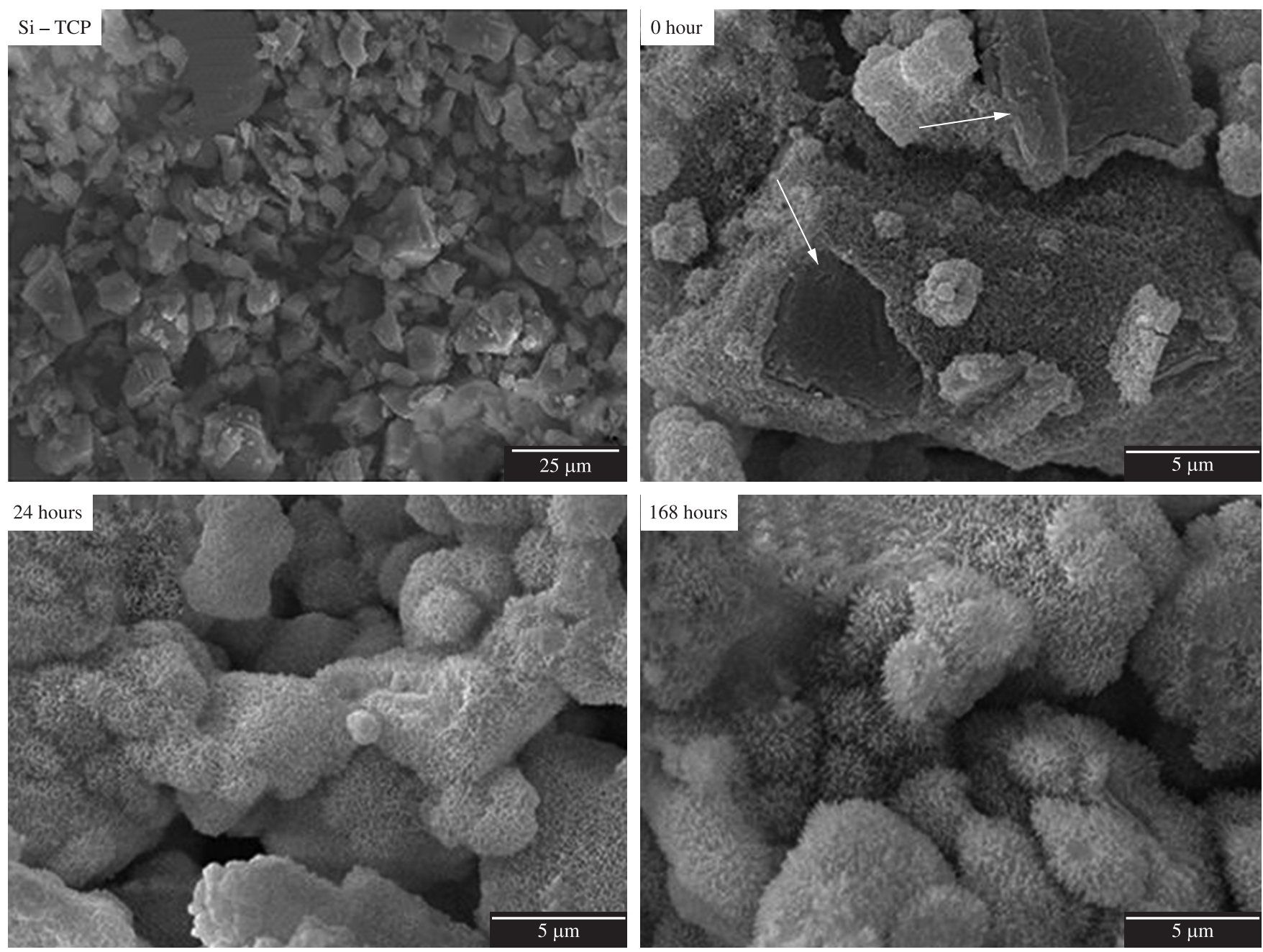

Figure 4. SEM micrographs of Si-TCP powder, cement sample after 24 hours $100 \%$ of relative moisture (0 hour) and cement samples after 24 hours and 168 hours of SBF immersion. The white arrows indicate $\alpha$-TCP grains without reacting. 
Moreover, it is possible to verify that due to wollastonite $\left(\mathrm{CaSiO}_{3}\right)$ addition and to $\mathrm{Mg}$ substitution into some $\mathrm{Ca}^{2+}$ sites a tiny deviation on the system stoichiometry (calcium excess) has occurred leading to

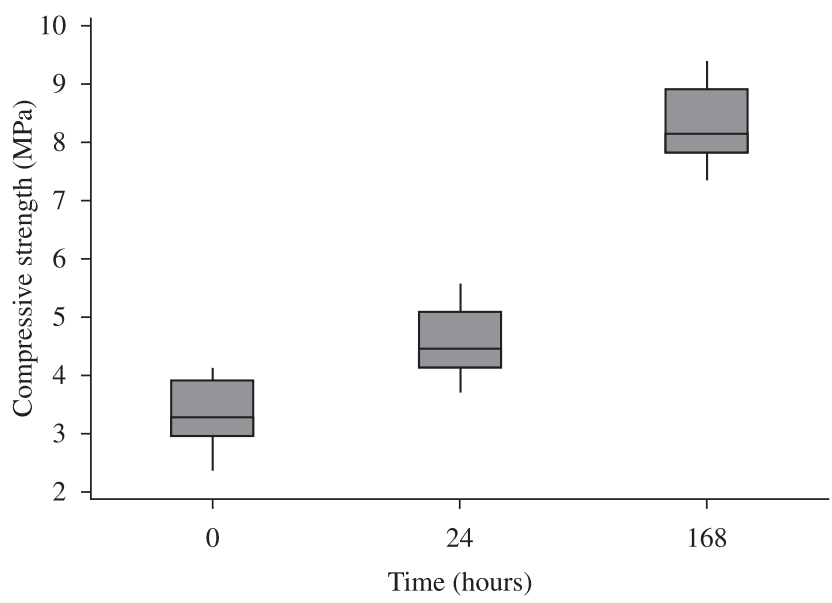

Figure 5. Cement samples compressive strength evolution with time. SBF immersion was responsible for the mechanical resistance enhancement. After ANOVA statistic analysis all samples can be considered to be statistically different $(\mathrm{p}<0.005)$. the formation of calcium oxide $(\mathrm{CaO})$ after sintering at $1400{ }^{\circ} \mathrm{C}$ (the * on Figure 1). Nonetheless, the values of $\mathrm{Ca} /(\mathrm{P}+\mathrm{Si})$ and $(\mathrm{Ca}+\mathrm{Mg}) /$ $(\mathrm{P}+\mathrm{Si})$ ratios obtained by quantitative $\mathrm{XRF}$ (Table 2 ) was 1.49 and 1.50 , respectively. The presence of some $\mathrm{CaO}$ in the final material was responsible for $\mathrm{pH}$ increase during the setting reaction (Figure 3 ).

The keys to the synthesis of pure $\mathrm{Si}-\alpha-\mathrm{TCP}$ are to ensure the right stoichiometry (i.e. atomic ratio $\mathrm{Ca} /(\mathrm{P}+\mathrm{Si})=1.50)$; to exclude the presence of $\mathrm{Mg}$ in the reagents employed, and to reach the proper temperature for maturing $\alpha$-phase $e^{9,11,15}$. The first requisite is easily accomplished by using the solid state synthetic method, which allows the accurate weighting of the required amounts of each reactant. The second one may be achieved by employing $\mathrm{Mg}$-free reagents. A previous work ${ }^{13}$ proposed the synthesis of alpha-TCP ${ }^{16}$ precursors $\mathrm{CaCO}_{3}$ and $\mathrm{CaHPO}_{4}$ by wet precipitation in the presence of ethylenediamine tetraacetic acid (EDTA). In that work, it was verified that EDTA forms a stable complex with $\mathrm{Mg}$, preventing its co-precipitation with the Ca salt. The effectiveness of the proposed procedure was demonstrated by the low $\mathrm{Mg}$-contents of the obtained precursors and the phase purity of the Si- $\alpha$-TCP prepared from them ${ }^{13}$.

After 168 hours of ball milling, Si-TCP powder achieved a main particle size of approximately $15.5 \mu \mathrm{m}$, a $10 \%<\mathrm{d}<90 \%$ distribution between 0.84-39.66 $\mu \mathrm{m}$ and a specific BET surface area of $1.0293 \pm 0.0263 \mathrm{~m}^{2} . \mathrm{g}^{-1}$. Si-TCP powder morphology and the heterogeneous particle size distribution can be observed on Figure 4.

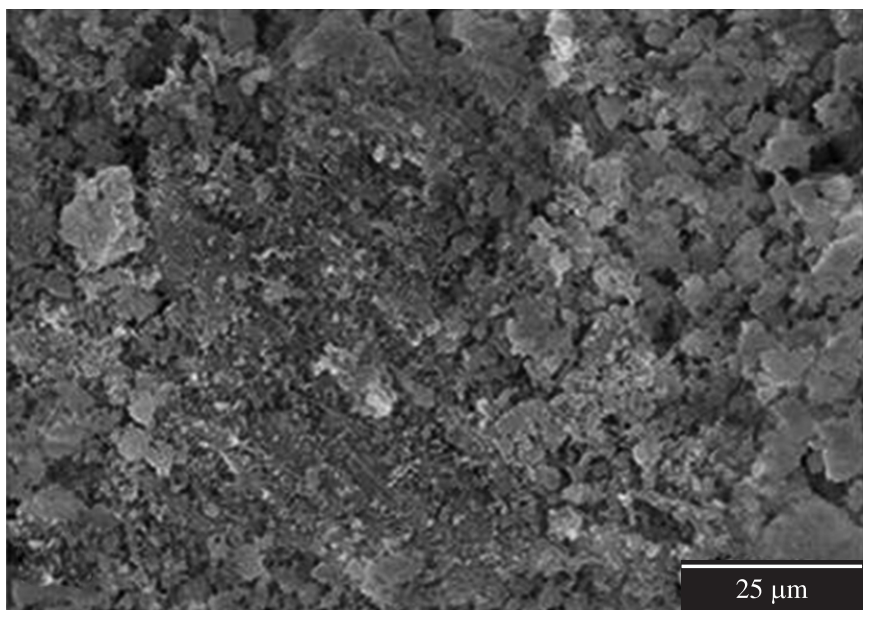

(a)

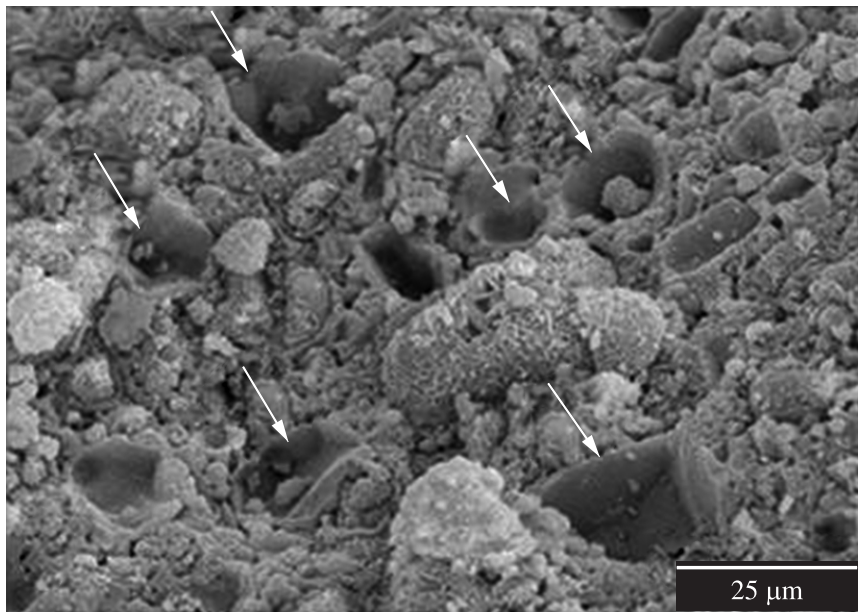

(c)

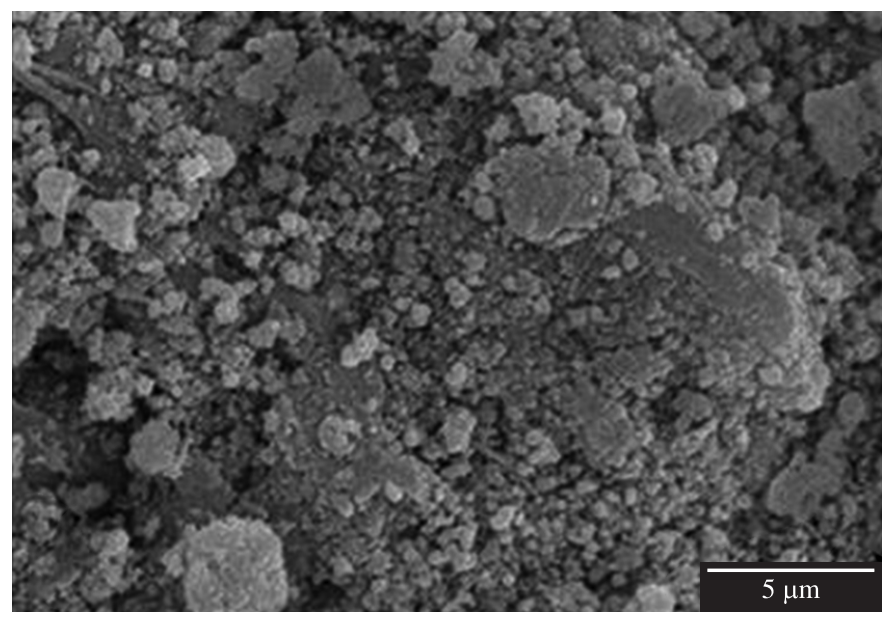

(b)

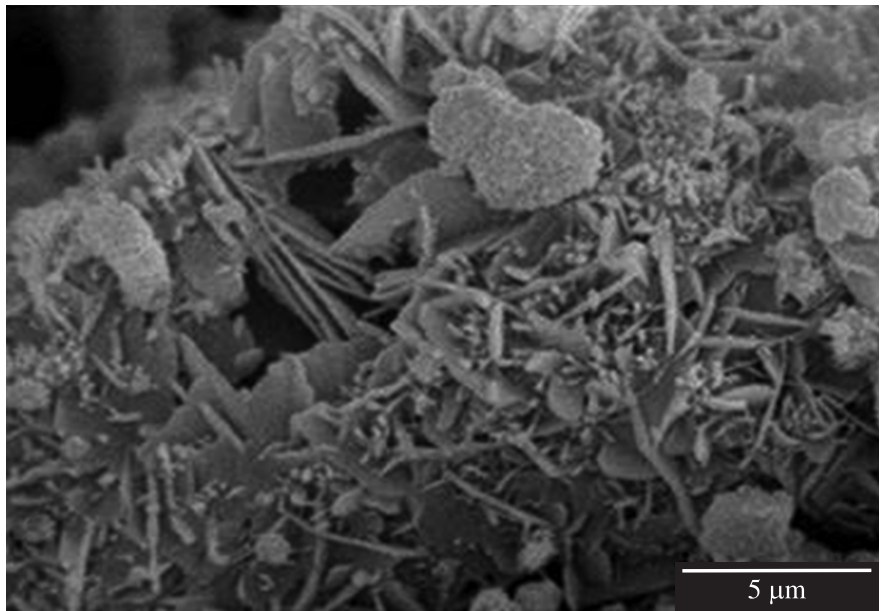

(d)

Figure 6. SEM micrographs of cement surface after 168 hours of setting (a and b) and an additional 168 hours of SBF immersion. The white arrows represent holes on the surface which are appeared as a result of the setting reaction continuation. The surface of these holes is also coated with an apatite layer. 
Si-TCP cement setting reaction occurs as expected for $\alpha$-TCP cement ${ }^{18}$. First, the superficial dissolution of the TCP grains occurs and after reaching the ionic saturation for apatite, tiny apatite crystals precipitate on this same surface. The white arrows of Figure 4 indicate TCP grains surrounded by an apatite layer which was fractured during the compressive mechanical testing. As the setting reaction evolves more TCP particles are dissolved and more apatite crystals are precipitated as can be observed on XRD patterns and SEM micrographs of the surface of fracture of cement samples after several setting times (Figure 1 and Figure 4, respectively). Moreover, comparing SEM micrographs for samples at 24 and 168 hours of reaction it was verified that the apatite crystals has grown as a function of immersion time.

Although the process involved on the cement setting reaction occurred as reported on the literature ${ }^{18}$, the rate by which Si-TCP evolves into apatite is very low compared to the values normally encountered $^{20,21}$. This fact could be attributed to many reasons: i) Si-TCP small surface area ${ }^{20}$; ii) high $\beta$-TCP weight contents ${ }^{18,21}$ and; iii) the presence of $\mathrm{CaO}$ which raises environment $\mathrm{pH}$ making difficult TCP dissolution and apatite precipitation. Indeed, in Figure 3 it is possible to verify that after 48 hours $\mathrm{pH}$ value is 8.39 and it only reach physiological values after 14 days. For instance, on XRD diffractograms (Figure 1) $\alpha$-TCP $\rightarrow$ apatite reaction is not complete even after 7 days. Furthermore, it is important to highlight that the setting reaction resulted on a carbonated apatite phase due to the $\mathrm{CO}_{3}^{2-}$ characteristics bands at 850 to 900 and at 1350 to $1600 \mathrm{~cm}^{-1}$ highlighted with a "+" on Figure 2. Unfortunately, it was not possible to verify any $\mathrm{Si}-\mathrm{O}$ absorbance bands on cement spectrums; thus, to verify the precipitation of silicon doped apatite during Si-TCP cement setting reaction it is necessary to investigate this fact more deeply.

Apatite crystal size evolution was responsible for compressive strength enhancement with time of the cement samples. As displayed on Figure 5, at initial times the samples did not present a considerable mechanical resistance $(3.35 \pm 0.59$ and $4.54 \pm 0.62 \mathrm{MPa}$, at zero and 24 hours of SBF immersion, respectively). As the setting reaction evolves and the apatite crystals entanglement became more cohesive, compressive strength raises, however, as observed on the box plot for cement at 168 hours the maximum mechanical resistance achieved $(8.32 \pm 0.67 \mathrm{MPa})$ is very low when compared to the values reported on the literature, $30-60 \mathrm{MPa}^{7,18}$. This fact can be attributed to the high levels of $\beta$-TCP (19 wt. (\%)) and the low reactivity of the Si-TCP powder. In fact, on Figure 1 it is possible to verify that even after 168 hours of reaction there still some visible XRD peaks of $\alpha$-TCP. The presence of no reacted particles ( $\beta$ and $\alpha$-TCP) acts as stress concentration points and the material fail faster. Moreover, the low mechanical resistance can be attributed to the high liquid-to-powder ratio employed $\left(0.60 \mathrm{~mL} . \mathrm{g}^{-1}\right)$ which increases porosity leading to more fragile materials.

Cement bioactivity in SBF can be verified in Figure 6 as a visible apatite layer was precipitated on sample's surface after 168 hours of immersion. The superficial "holes" (indicated with white arrows on Figure 6) were a result of the evolution of setting reaction. Probably, $\alpha$-TCP particles which did not react after 168 hours were dissolved during the bioactivity assay. Moreover, the surface of the superficial "holes" is coated with apatite particles. Notwithstanding, to ensure that silicon is the element responsible for increasing the materials bioactivity ${ }^{7,12,14}$ it is necessary to evaluate the in vivo performance of the bone cement obtained in this work.

\section{Conclusion}

It was possible to synthesize at $1400^{\circ} \mathrm{C}$ silicon doped tricalcium phosphate by mixing $\mathrm{CaCO}_{3}, \mathrm{CaHPO}_{4}$ and $\mathrm{CaSiO}_{3}$. Nevertheless, due to high $\mathrm{Mg}$ contamination, $\alpha$-TCP was formed with 19 wt. (\%) of $\beta$-TCP as impurity.

Cement setting reaction take place by the same steps of conventional $\alpha$-TCP cement; however, the rate of reaction was very low and TCP $\rightarrow$ apatite conversion was not complete even after 168 hours as a result of $\beta$-TCP and $\mathrm{CaO}$ contamination which dissolution processes compete with $\alpha$-TCP dissolution and apatite precipitation.

Even though the cement developed in this work did not achieve a satisfactory mechanical performance, the bioactivity in SBF may be taken into account for encouraging further investigation and optimization of its properties. Notwithstanding, to ensure that silicon is the element responsible for increasing the materials bioactivity it is necessary to evaluate the in vivo performance of the bone cement obtained in this work.

\section{Acknowledgement}

The State of São Paulo Foundation (FAPESP) and the INCTBiofabris for the financial support

\section{References}

1. Wei X, Ozan U, Ankit A, Acar HY and Akinc M. Dissolution behavior of $\mathrm{Si}, \mathrm{Zn}$-codoped tricalcium phosphate. Materials Science and Engineering C. 2009; 29(1):126-135. http://dx.doi.org/10.1016/j.msec.2008.05.020

2. Matsumoto N, Yoshida K, Hashimoto K and Toda Y. Thermal Stability of $\beta$-tricalcium phospahte doped with monovalent metal ions. Materials Research Bulletin. 2009; 44(9):1889-1894. http://dx.doi.org/10.1016/j. materresbull.2009.05.012

3. Li X, Ito A, Sogo Y, Wang X and LeGeros RZ. Solubility of Mg-containing $\beta$-tricalcium phosphate at $25^{\circ} \mathrm{C}$. Acta Biomaterialia. 2009; 5(1):508-517. http://dx.doi.org/10.1016/j.actbio.2008.06.010

4. Pietak AP, Reid JW, Stott MJ and Sayer M. Silicon Substituition in the Calcium Phosphate Bioceramics. Biomaterials. 2007; 28(28):4023-4032. http://dx.doi.org/10.1016/j.biomaterials.2007.05.003

5. Arcos D, Sanchez-Salcedo S, Izquierdo-Barba I, Ruiz L, GonzalezCalbet J and Vallet-Regi M. Crystallochemistry, textural properties, and in vitro biocompatibility of different silicon-doped calcium phosphates. Journal of Biomedical Meterial Research Part A. 2006; 78(4):762-771. http://dx.doi.org/10.1002/jbm.a.30790

6. Camiré CL, Jegou Saint-Jean S, McCarthy I, Mochales-Palau C, Lidgren L, Planell JA et al. Production Methodology and Reactivity of Silica Substituted $\alpha$ phase Tricalcium Phosphate. In: Proceedings ofth 7 th World Biomaterials Congress; 2004; Sydney, Australia. Sydney; 2004.

7. Camiré CL, Saint-Jean SJ, Mochales C, Nevsten P, Wang JS, Lidgren L et al. Material Characterization and In Vivo Behavior of Silicon Substituted a-Tricalcium Phosphate Cement. Journal of Biomedical Material Research Part B: Applied Biomaterials. 2006; 76(2):424-431.

8. Reid JW, Pietak A, Sayer M, Dunfield D and Smith TJ Phase formation and evolution in the silicon substituted tricalcium phosphate/apatite system. Biomaterials. 2005; 26(16):2887-2897. http://dx.doi.org/10.1016/j. biomaterials.2004.09.005

9. Reid JW, Tuck L, Sayer M, Fargo K and Hendry JA. Shynthesis and Characterization of Single-Phase Silicon-Substituted $\alpha$-Tricalcium Phosphate. Biomaterials. 2006; 27(15):2916-2925. http://dx.doi. org/10.1016/j.biomaterials.2006.01.007

10. Langstaff S, Sayer M, Smith TJ, Pugh SM, Hesp SA and Thompson WT. Resorbable bioceramics based on stabilized calcium phosphates. Part I: rational design, sample preparation and material characterization. Biomaterials. 1999; 20(18):1727-1741. http://dx.doi.org/10.1016/S01429612(99)00086-1

11. Carrodeguas RG and De Aza S. Alpha-Tricalcium phosphate: synthesis, properties and biomedical applications. Acta Biomateriallia. 2011; in press. 
12. Gaspar AMM, Saska S, Carrodeguas RG, De Aza AH, Pena P, De Aza PN et al. Biological response to wollastonite doped $\alpha$-tricalcium phosphate implants in hard and soft tissues in rats. Key Engineering Materials. 2009; 396-398:7-10.

13. Motisuke M, Carrodeguas RG and Zavaglia CAC. Mg-free precursors for the synthesis of pure phase Si-doped $\alpha-\mathrm{Ca} 3(\mathrm{PO} 4) 2$. Key Engineering Materials. 2008; 361-363: 199-202. http://dx.doi.org/10.4028/www. scientific.net/KEM.361-363.199

14. Carrodeguas RG, De Aza AH, Jimenez J, De Aza PN, Pena P, LópezBravo A et al. Preparation and in vitro characterization of wollastonite doped tricalcium phosphate bioceramics. Key Engineering Materials. 2008; 361-363:237-240. http://dx.doi.org/10.4028/www.scientific.net/ KEM.361-363.237

15. Reid JW, Fargo K, Hendry JA and Sayer M. The Influence of Trace Magnesium Content on the Phase Composition of Silicon-Stabilized Calcium Phosphate Powders. Materials Letters. 2007; 61(18):3851-3854. http://dx.doi.org/10.1016/j.matlet.2006.12.046

16. Carrodeguas RG, De Aza A H, Turrillas X, Pena P and De Aza S. New approach to the $\beta \rightarrow \alpha$ polymorphic transformation in magnesiumsubstituted tricalcium phosphates and its pratical implications. Journal of the American Ceramic Society. 2008; 91(4):1281-1286. http://dx.doi. org/10.1111/j.1551-2916.2008.02294.x

17. Cullity BD. Elements of X-Ray Diffraction. Indiana: Addion-Wesley Publishing Company, Inc.; 1977.

18. Ginebra MP, Fernández E, De Maeyer EA, Verbeeck RM, Boltong MG, Ginebra J et al. Setting Reaction and Hardening of an Apatitic Calcium Phosphate Cement. Journal of Dental Research. 1997; 76(4):905-912. http://dx.doi.org/10.1177/00220345970760041201

19. Dunfield D, Sayer M and Shurvell HF. Total Attenuated Reflection Infrared Analysis of Silicon-Stabilized Tri-Calcium Phosphate. The Journal of Physical Chemistry B. 2005; 109(42):19579-19583. http://dx.doi.org/10.1021/jp0519823

20. Ginebra MP, Driessens FCM and Planell JA. Effect of the Particle Size on the Micro and Nanostructural Features of a Calcium Phosphate Cement: a Kinetics Analysis. Biomaterials. 2004; 25(17):3453-3462. http://dx.doi. org/10.1016/j.biomaterials.2003.10.049

21. Ginebra MP, Fernandez E, Driessens FCM and Planell JA. Modeling of the Hydrolysis of $\alpha$-Tricalcium Phosphate. Journal of the American Ceramic Society. 1999; 82(10):2808-2812. http://dx.doi. org/10.1111/j.1151-2916.1999.tb02160.x 